\title{
PENGGUNAAN TEKNOLOGI UV-Vis SPECTROSCOPY UNTUK MEMBEDAKAN JENIS KOPI BUBUK ARABIKA GAYO WINE DAN KOPI BUBUK ARABIKA GAYO BIASA
}

\section{THE USE OF UV-VIS SPECTROSCOPY TECHNOLOGY TO DISCRIMINATE GROUND ROASTED ARABICA WINE GAYO COFFEE AND GROUND ROASTED ARABICA NORMAL GAYO COFFEE}

\author{
Diding Suhandy ${ }^{1 \otimes}$, Eny Supriyanti $^{1}$, Meinilwita Yulia ${ }^{2}$, Sri Waluyo ${ }^{1}$ \\ ${ }^{1}$ Jurusan Teknik Pertanian, Fakultas Pertanian, Universitas Lampung \\ ${ }^{2}$ Program Studi Mekanisasi Pertanian, Politeknik Negeri Lampung \\ ${ }^{\square}$ Komunikasi Penulis, e-mail: diding.sughandy@fp.unila.ac.id \\ DOI:http://dx.doi.org/10.23960/jtep-l.v7i3.123-132 \\ Naskah ini diterima pada 01 Agustus 2018; revisi pada 18 September 2018; \\ disetujui untuk dipublikasikan pada 31 Oktober 2018
}

\begin{abstract}
One of the specialty coffee of Indonesian is wine Arabica Gayo coffee which is a variety of selection result developed by Indonesian farmers. This research aims to develope and evaluate model of discrimination to identify and classify of ground roasted Arabica wine Gayo coffee and ground roasted Arabica normal Gayo coffee. The research was conducted on the ground roasted coffee with particle size of 0,297 millimeters (mesh 50). Each spectrum of aqueus samples was measured twice treatment to each sample using UV-Vis spectroscopy Genesys 10s in wavelength range of 190-1100 $\mathrm{nm}$. Data were processed using principal component analysis (PCA) to see clustering all data. After that, for discrimination model was built using soft independent modeling of class analogy (SIMCA) method for original and pretreatment spectra. The best classification result was obtained method of Multiplicative Scatter Correction (MSC) and Moving Average 9 segmen which can explains the values of various data with value PC1 97\% and PC2 3\%. Data classification obtained the values of accuracy(AC) 100\%, specificity(SP) 100\%, and sensitivity(S) 100\% with a value error (FP) of 0\%. Based on these results on all tests, the SIMCA model built can identify and classify prediction coffee samples into corresponding class with accepted result.
\end{abstract}

Keywords: Normal Gayo Arabica coffee, Wine Gayo Arabica coffee, UV-Vis spectroscopy, PCA, SIMCA

\begin{abstract}
ABSTRAK
Salah satu kopi spesialti Indonesia adalah kopi Arabika Gayo wine yang merupakan varietas hasil seleksi yang dikembangkan oleh petani Indonesia. Penelitian ini bertujuan untuk membangun dan menguji model diskriminasi untuk mengidentifikasi dan mengklasifikasikan kopi bubuk Arabika Gayo wine dan kopi bubuk Arabika Gayo biasa. Pengujian dilakukan pada bubuk kopi berukuran 0,297 milimeter (mesh 50). Pengambilan spektra pada sampel hasil ekstraksi dilakukan sebanyak 2 kali pengulangan untuk setiap sampel menggunakan Spektrometer UV-Vis Genesis 10s pada rentang panjang gelombang 190-1100 nm. Data spektra diolah menggunakan metode PCA untuk melihat pengelompokkan semua data. Setelah itu, untuk model diskriminasi dibangun menggunakan metode SIMCA untuk spektra original dan petreatment. Hasil klasifikasi terbaik yaitu pada metode multiplicative scatter correction (MSC) dan moving average 9s yang menjelaskan nilai keragaman data dengan nilai PC1 97\% dan PC2 3\%. Sedangkan untuk klasifikasi data diperoleh nilai akurasi (AC) 100\%, spesifisitas (SP) 100\%, dan sensitivitas (S) 100\%, dengan nilai eror (FP) 0\%. Berdasarkan hasil ini pada semua pengujian. maka model SIMCA yang dibangun dapat mengidentifikasi dan mengklasifikasikan sampel kopi prediksi ke dalam kelas yang sesuai dengan baik.
\end{abstract}

Kata Kunci: Kopi Arabika Gayo biasa, kopi Arabika Gayo wine, UV-Vis spectroscopy, PCA, SIMCA. 


\section{PENDAHULUAN}

Kopi merupakan salah satu komoditas ekspor yang mendatangkan devisa bagi negara. Produksi kopi global diperkirakan mencapai 159,66 juta tas di tahun 2017/18 atau sekitar 1,2\% lebih tinggi dari 2016/17, dan menghasilkan surplus sebesar 0,78 juta tas. Namun, pada Maret 2018, produksi kopi menurun sebesar $1,1 \%$ menjadi 112,99 sen US\$/pon dan mencapai titik terendah 110,73 sen US\$/pon pada 23 Maret 2018 (ICO,2018). Kopi menjadi salah satu hasil pertanian yang disenangi banyak orang karena dapat diolah menjadi minuman yang memiliki aroma dan rasanya yang nikmat, serta berpotensi sebagai obat-obatan dan penahan rasa kantuk (Panggabean, 2011).

Kopi termasuk salah satu tanaman perkebunan yang penting dan memiliki nilai ekonomis tinggi. Produksi kopi merupakan penyokong perekonomian melalui basis produksi bahan bahan mentah dan basis penyerapan tenaga kerja (Sahat, 2015). Salah satu andalan ekspor kopi Indonesia adalah kopi Gayo yang merupakan varietas hasil seleksi yang dikembangkan oleh petani yang produksinya terus mengalami peningkatan. Faktor penting untuk peningkatan ekspor kopi Arabika Gayo adalah mutu biji yang tinggi (Maramis et al.2013).

Kopi Gayo merupakan kopi yang diproduksi di Kabupaten Bener Meriah, Aceh Tengah, dan Gayo Lues. Ketiga daerah tersebut berada di wilayah Nanggroe Aceh Darussalam, Sumatera, Indonesia. Produksi kopi arabika Gayo terjadi penurunan pada tahun 2017 yaitu 46.828 ton dari 47.378 ton pada tahun 2016 setelah 9 tahun terakhir terus mengalami peningkatan, namun pada tahun 2016-2017 terjadi peningkatan ekspor kopi Gayo sebesar 200\% (Ditjenbun,2017).Harga biji kopi Arabika Gayo

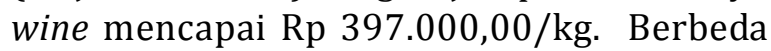
dengan harga kopi Arabika Gayo biasa yang dibandrol dengan harga Rp 100.000,00/kg. Kedua kopi ini berasal dari biji kopi yang sama yaitu kopi Arabika Gayo varietas ateng super, perbedaan harga dapat mengacu terhadap perbedaan kualitas kedua kopi tersebut. Secara visual sangat sulit untuk menemukan perbedaan dari kopi bubuk Arabika Gayo wine dengan kopi Arabika Gayo biasa.
Terdapat beberapa metode yang dapat digunakan untuk menemukan perbedaan dari kedua kopi tersebut, di antaranya adalah metode organoleptik. Metode organoleptik memiliki kelemahan yaitu bersifat subyektif karena manusia di pengaruhi kondisi fisik yang berbeda dan keterbatasan akibat beberapa sifat indrawi yang tidak dapat dideskripsikan. Metode lain yang digunakan adalah metode NIR (Near Infra Red), metode ini memiliki beberapa kelemahan yaitu peralatan yang digunakan mahal dan biaya perawatannya tinggi sehingga teknologi NIR sulit diaplikasikan ke masyarakat. Selanjutnya adalah metode GC (Gas Chromatography) dan HPLC (High Performance Liquid Chromatography), kedua metode tersebut merupakan metode kromatografi kinerja tinggi tetapi metode-metode tersebut memiliki kelemahan yaitu peralatan yang digunakan sangat mahal dan metode analisisnya membutuhkan waktu yang cukup lama. Oleh karena itu dalam penelitian ini digunakan metode teknologi UV-Vis Spectroscopy.

Banyak peneliti yang menggunakan metode $U V$ Vis Spectroscopy untuk mengidentifikasi perbedaan maupun pemalsuan kopi. Iriani (2016) membuktikan bahwa teknologi UV-Vis Spectroscopy dapat membedakan kopi luwak yang dicampur kopi Arabika dengan kopi luwak asli secara cepat dan Pratiwi(2018) yang menggunakan UV-Vis Spectroscopy untuk diskriminasi beberapa kopi specialty Indonesia. Teknologi ini memiliki banyak kelebihan yaitu peralatan dengan harga terjangkau, mudah diaplikasikan ke masyarakat, dan metode analisisnya tepat serta cepat.

Teknologi UV-Vis Spectroscopy tepat digunakan untuk membedakan kopi Arabika Gayo wine dengan kopi Arabika Gayo biasa. Kopi tersebut akan dibedakan berdasarkan sifat optik dengan menggunakan UV-Vis Spectroscopy untuk mendapatkan absorban data. Dari absorban data yang sudah didapat kemudian dianalisis dengan teknik kemometrik menggunakan analisis multivariat (berpeubah banyak).

Analisis multivariat merupakan salah satu teknik statistik yang digunakan untuk memahami struktur data dalam dimensi tinggi. Analisis multivariat yang digunakan dalam penelitian ini 
yaitu principal component analysis (PCA) dan soft independent modelling of class analogy (SIMCA). Penelitian ini bertujuan untuk membangun dan menguji model diskriminasi kualitatif untuk mengidentifikasi dan mengklasifikasikan kopi Arabika Gayo wine dengan kopi Arabika Gayo biasa.

\section{BAHAN DAN METODE}

Penelitian ini telah dilaksanakan pada bulan Desember 2017 di Laboratorium Rekayasa Bioproses dan Pasca Panen, Jurusan Teknik Pertanian, Fakultas Pertanian, Universitas Lampung.

Alat yang digunakan dalam penelitian ini yaitu Genesys 10 UV-Vis Spectroscopy, cuvet, mesh, rubber bulb, aluminium foil, ayakan tyler meinzer II, stirrer model S130810-33 (size pelat atas $4 \times 4$, tegangan 220-240 volt, kecepatan pengadukan $6(350 \mathrm{rpm}))$, beaker glass, labu erlenmeyer $50 \mathrm{ml}$, botol semprot, pemanas air, toples, botol transparan, termometer, timbangan digital, kertas saring, pengaduk, spatula, pipet ukur ( $1 \mathrm{ml}, 2 \mathrm{ml}, 25 \mathrm{ml}$ ), gelas ukur, dan corong plastik. Sedangkan bahan yang digunakan yaitu tissue, aquades, kopi bubuk Arabika Gayo wine, dan kopi bubuk Arabika Gayo biasa yang dibeli di toko kopi terpercaya di Nanggroe Aceh Darussalam. Prosedur penelitian ditampilkan pada Gambar 1.

\subsection{Ekstraksi Kopi}

Sampel untuk pengujian yang berupa bubuk harus diekstrak menjadi larutan agar dapat diuji menggunakan alat spektrometer dengan mencampurkan 1 gram sampel bersama aquades sebanyak $50 \mathrm{ml}$ pada suhu $90-98^{\circ} \mathrm{C}$. Selanjutnya dilakukan pengadukan menggunakan stirrer model S130810-33 (size pelat atas $4 \times 4$, tegangan 220-240 volt, kecepatan pengadukan 6 (350 rpm), selama 10 menit untuk menghomogenkan larutan kopi. Kemudian sampel yang sudah terlarut dan homogen disaring untuk memisahkan ampas kopi dengan hasil ekstrak kopi. Ekstrak kopi yang dihasilkan pada langkah penyaringan kemudian didinginkan hingga mencapai suhu $27^{\circ} \mathrm{C}$, selanjutnya dilakukan pengenceran dengan perbandingan 1:20.

\subsection{Pengambilan Spektra Menggunakan Spektrometer}

Teknologi UV-Vis Spectroscopy yang digunakan yaitu Genesys 10 UV-Vis Spectroscopy. Sebelum dilakukan pengambilan spektra, dilakukan setting pada teknologi UV-Vis Spectroscopy yaitu pengambilan data dari panjang gelombang 190$1100 \mathrm{~nm}$. Kemudian dilakukan kalibrasi menggunakan larutan aquades yang disebut Blank. Lalu, sampel yang telah diencerkan kemudian dimasukkan ke dalam cuvet sebanyak $2 \mathrm{ml}$. Selanjutnya dimasukkan dalam sistem holder dan diukur nilai absorbannya selama 2 menit hingga proses mencapai $100 \%$. Setelah selesai akan keluar graph (grafik) kemudian data absorban disimpan dalam USB drive.

\subsection{Analisis Data}

Analisis data dilakukan untuk mendeteksi pola sampel menggunakan perangkat lunak The Unscrambler versi 9.2. Model kalibrasi dibangun menggunakan metode principal component analysis (PCA) dan soft independent modeling of class analogy (SIMCA). Sampel yang sudah didapatkan nilai absorbannya selanjutnya digabungkan menjadi satu dalam Microsoft Excel 1997-2003 kemudian dianalisis ke aplikasi The Unscrambler. Setiap 200 sampel jenis kopi akan dibagi menjadi sampel kalibrasi sebanyak 100 sampel, validasi sebanyak 60 sampel dan sampel prediksi sebanyak 40 sampel. Sampel kalibrasi untuk membuat Model SIMCA dan sampel prediksi untuk menguji model tersebut. Setelah hasil klasifikasi dari pengujian model didapatkan kemudian dilakukan perhitungan menggunakan confusion matrix.

\section{HASIL DAN PEMBAHASAN}

\subsection{Analisis Spektra Kopi Gayo Wine dan Kopi Gayo Biasa}

Data tersebut menunjukan garis yang mengalami perbedaan pada hasil absorban yaitu pada panjang gelombang 240-360 nm. Panjang gelombang 200-500 nm untuk standar pengukuran asam klorogenat (Farhaty dan Muchtariadi,2016). Pada panjang gelombang $272 \mathrm{~nm}-275 \mathrm{~nm}$ merupakan kurva penentuan standard senyawa trigonelin, panjang gelombang $276 \mathrm{~nm}-280 \mathrm{~nm}$ merefleksikan 


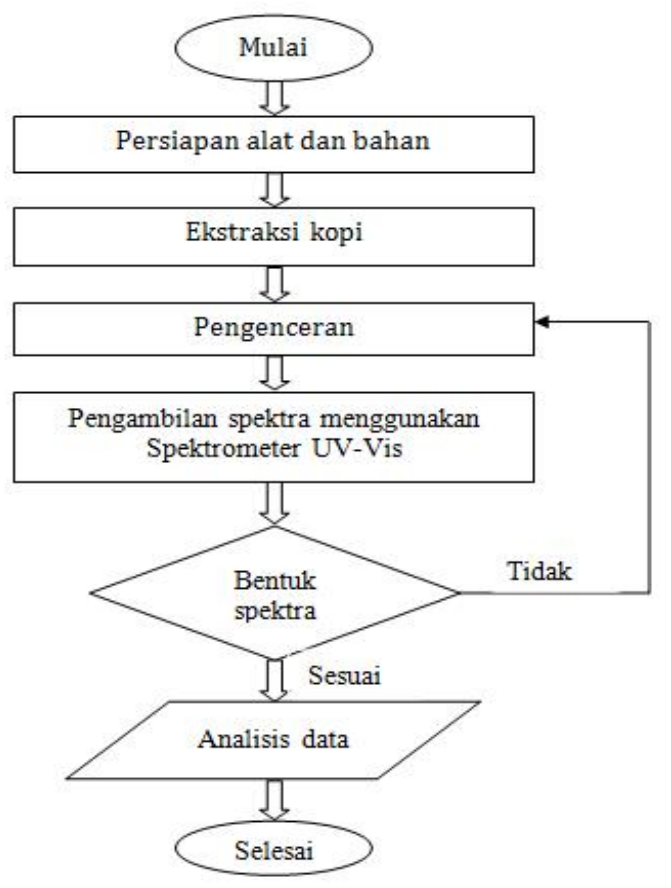

Gambar 1. Prosedur Penelitian

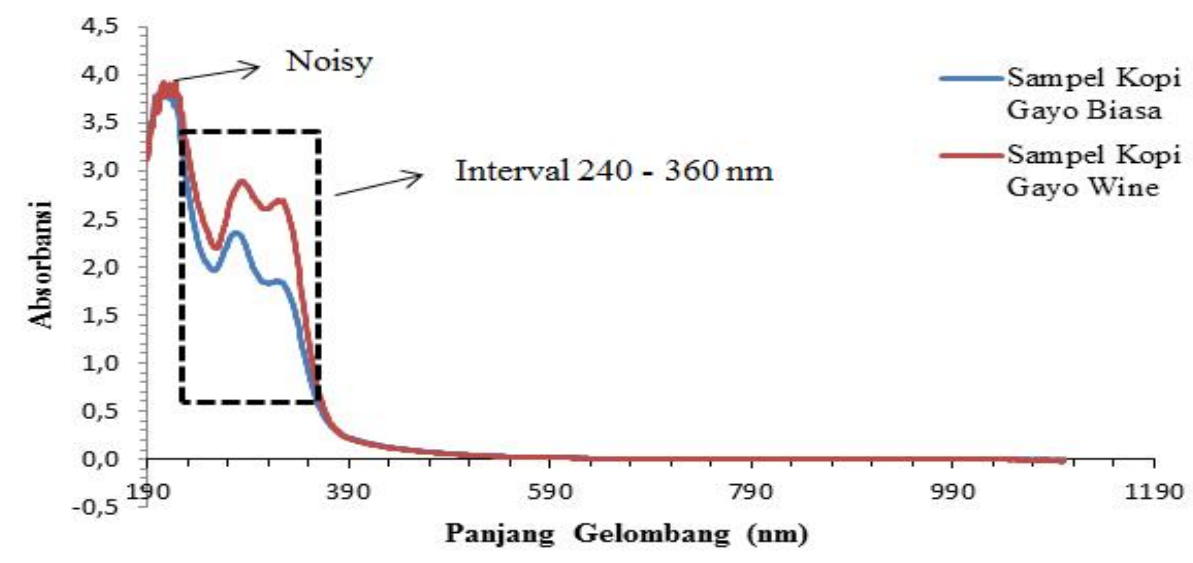

Gambar 2. Grafik Spektra Original pada Panjang Gelombang 190-1100 nm

kandungan kafein, sedangkan panjang gelombang $320 \mathrm{~nm}-325 \mathrm{~nm}$ merepresentasikan absorbansi dari asam kafein (Souto et al.,2015). Pada kopi Gayo wine memiliki garis yang lebih tinggi dibandingkan garis pada kopi Gayo biasa, karena jika kandungan senyawa dalam kopi lebih tinggi maka nilai absorban juga lebih tinggi. Dengan adanya perbedaan nilai absorban tersebut maka kopi Gayo biasa dan kopi Gayo wine dapat dibedakan secara kualitatif.

\subsection{Hasil PCA Menggunakan Spektra Orginal}

Gambar 3 merupakan hasil plot PCA dari 400 sampel kopi yang terdiri dari 200 sampel kopi Gayo biasa dan 200 sampel kopi Gayo wine.
Dapat dilihat bahwa kedua jenis sampel kopi tersebut terpisah dan tidak saling bercampur. Kopi Gayo wine memiliki nilai PC1 positif, sedangkan kopi Gayo biasa sebagian besar memiliki nilai PC1 negatif, sehingga hal tersebut menjelaskan bahwa kedua kopi ini dapat dibedakan oleh PC1. Meskipun ada beberapa sampel yang letaknya berjauhan dari kelompok sampel, tetapi sampel tersebut masih terikat dalam kumpulan kelompoknya dan tidak tergabung dengan kelas sampel yang berbeda jenis. Hal tersebut berarti data absorban yang diperoleh dari Uv-Vis Spectroscopy adalah data yang bagus dan konsisten. Hasil plot diskriminasi PCA pada PC1 (97\%) dan PC2 (2\%), jika dijumlahkan kedua PC tersebut didapatkan hasil 


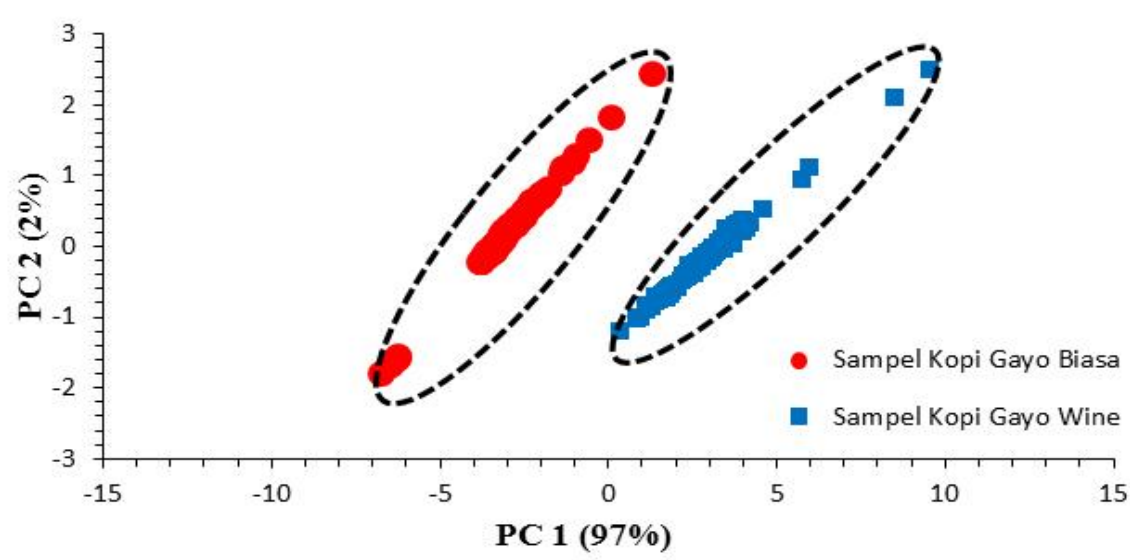

Gambar 3. Hasil Plot PCA Menggunakan Spektra Original

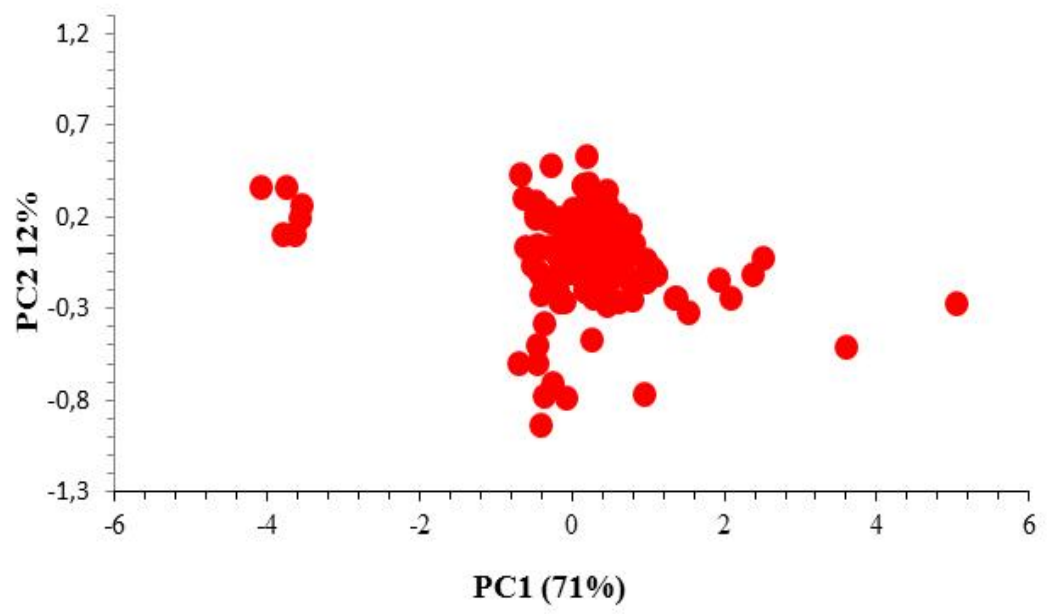

Gambar 4. Model SIMCA Sampel Kopi Gayo Biasa Menggunakan Spektra Original

total varians sebesar $99 \%$. Hasil total varians tersebut dengan jumlah persentase $99 \%$ sudah dapat dikatakan baik untuk membangun sebuah model. Menurut Nurcahyo (2015), jika jumlah peubah dari komponen utama satu PC1 dan dua PC2 lebih besar dari 70\%, maka hasil plot komponen utama memperlihatkan dua dimensi yang baik.

\subsection{Model SIMCA Menggunakan Spektra Original}

Hasil dari pembuatan SIMCA pada kopi Gayo wine dan kopi Gayo biasa masing-masing dapat dilihat pada Gambar 4 dan Gambar 5. Berdasarkan Gambar 4 dan Gambar 5, hasil dari model SIMCA kopi Gayo biasa dan model SIMCA kopi Gayo wine pada panjang gelomban penuh (190-1100 nm) sampelnya tersusun berkelompok, meskipun masih ada beberapa model yang sedikit terpencil. Susunan model tersebut merupakan hasil yang diperoleh pada pengolahan aplikasi The Unscrambler versi 9.2. Pada model SIMCA kopi Gayo biasa memiliki nilai PC1 sebesar 71\% dan nilai PC2 sebesar 12\%. Sedangkan pada model SIMCA kopi Gayo wine terlihat nilai PC1 sebesar 93\% dan PC2 sebesar $1 \%$. Berdasarkan data tersebut, jika dijumlahkan pada kopi Gayo biasa memiliki nilai model SIMCA sebesar 83\% dan pada kopi Gayo wine sebesar 94\%. Setelah dilihat dari hasil nilai PC1 dan PC2 kedua kopi Gayo Arabika tersebut dapat dikatakan bagus dan sesuai harapan untuk proses pendiskriminasian kopi.

\subsection{Klasifikasi Kopi Gayo Wine dan Kopi Gayo Biasa Menggunakan Spektra Original}

Setelah dilakukan klasifikasi terhadap 40 sampel prediksi Gayo biasa dan 40 sampel kopi Gayo wine, selanjutnya dilakukan perhitungan Confusion Matrix. Perhitungan Confusion Matrix dapat dilihat pada Tabel 1. 


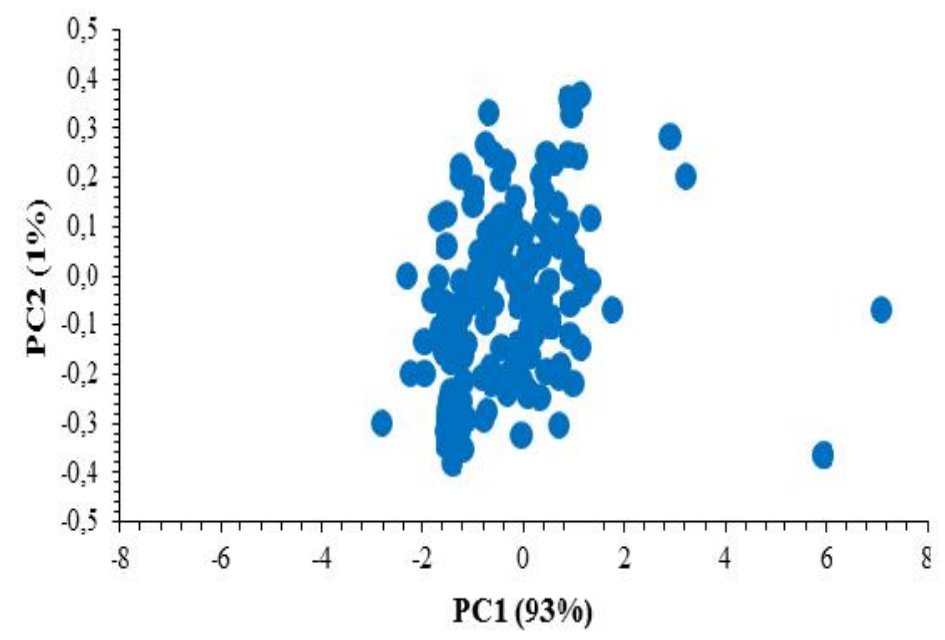

Gambar 5. Model SIMCA Sampel Kopi Gayo Wine Menggunakan Spektra Original

Tabel 1. Confusion Matrix Kopi Original

\begin{tabular}{lcc}
\hline & Kelas A (Model SIMCA A) & Kelas B (Model SIMCA B) \\
\hline Kelas A (aktual) & 39 & 0 \\
Kelas B (aktual) & 0 & 38 \\
\hline
\end{tabular}
a) Akurasi (AC)
$=\frac{a+d}{a+b+c+d} \times 100 \%=\frac{39+38}{39+0+0+38} \times 100 \%=100 \%$
b) Sensitivitas (S)
$=\frac{d}{b+d} \times 100 \%=\frac{38}{0+38} \times 100 \%=100 \%$
c) Spesifisitas (SP)
$=\frac{a}{a+c}$
$=\frac{c}{a+c} \times 100 \%=\frac{0}{39+0} \times 100 \%=0 \%$
d) Error (FP)

SIMCA kopi Arabika Gayo biasa. Sedangkan pada sampel prediksi kopi Arabika Gayo wine terdapat 38 sampel dari 40 sampel prediksi kopi Gayo wine yang masuk ke dalam model SIMCA kopi Gayo wine, terdapat 1 sampel prediksi Gayo biasa yang tidak masuk ke dalam SIMCA Gayo biasa yaitu sampe GB89A dan terdapat 2 sampel prediksi kopi Gayo wine yang tidak masuk ke dalam model SIMCA manapun yaitu sampel GW95A dan GW95B. Hal ini dapat dilihat pada grafik commons plot pada Gambar 6.

kategori sampel dengan sangat baik. Selain nilai Akurasi (AC), diperoleh juga nilai Sensitivitas (S) sebesar $100 \%$ yang menunjukan bahwa kemampuan model untuk membedakan kedua sampel tersebut sangat baik. Terdapat juga nilai Spesifisitas (SP) sebesar 100\%, hal ini berarti kemampuan model untuk mengarahkan kedua sampel tersebut sangat baik. Sedangkan nilai Error (FP) sebesar 0\% yang berarti model yang dibuat tersebut sangat baik dalam mengenali karakteristik sampel.

Hasil klasifikasi pada data spektra original menunjukan bahwa 39 dari 40 sampel prediksi kopi Arabika Gayo biasa masuk ke dalam model

Pada hasil klasifikasi ini tidak ada sampel yang masuk ke dalam 2 model sekaligus yaitu model SIMCA kopi Gayo biasa maupun model SIMCA kopi Gayo wine. Model yang tidak masuk klasifikasi kemungkinan terletak jauh dari kedua kuadran.

\subsection{Hasil PCA Menggunakan Spektra MSC+Moving Average $9 \mathrm{~s}$}

Metode MSC merupakan salah satu pendekatan untuk mengurangi Amplification (multiplicative, scattering) dan offset (additive, chemical) efek di spektrum. Tujuan utama MSC adalah untuk 


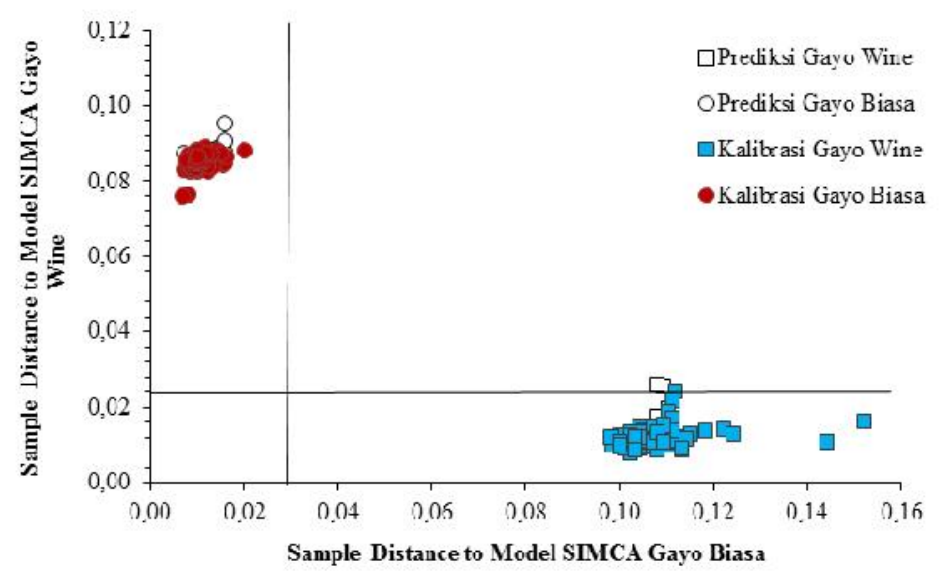

Gambar 6. Commans Plot Original Hasil Klasifikasi pada Microsoft Excel

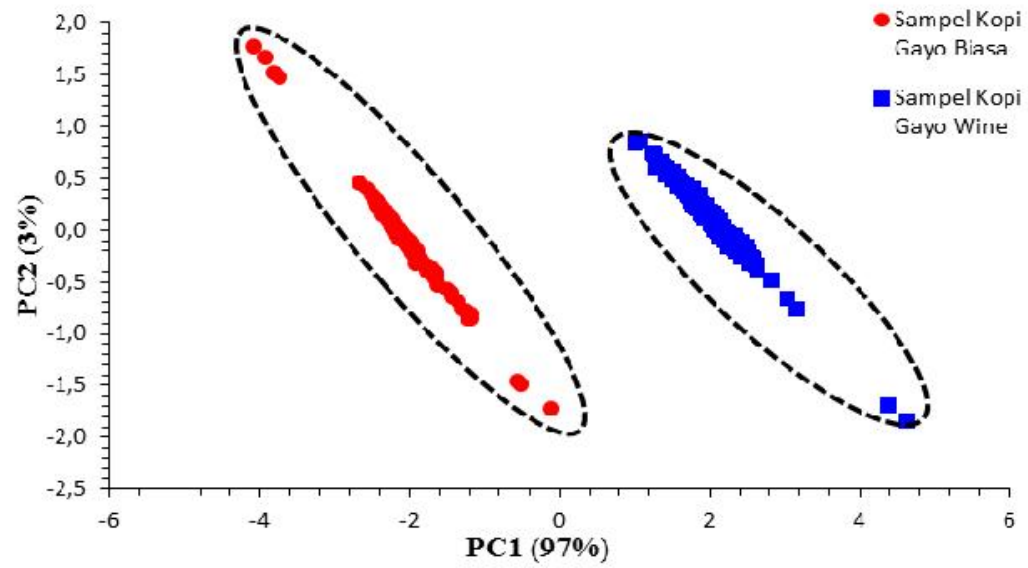

Gambar 7. Hasil Plot PCA Menggunakan Spektra MSC Moving Average 9 segmen

memperbaiki semua sampel sehingga semuanya memiliki tingkat hamburan cahaya yang sama (Pietro,2017).

Pada Gambar 7 terdapat hasil plot diskriminasi PCA MSC moving average 9 segmen di dalam plot tersebut terdapat nilai PC1 dan PC2 dari 400 sampel kopi. Berdasarkan gambar tersebut dapat dilihat bahwa kedua jenis kopi tersebut memiliki plot dengan kuadran terpisah, kopi Gayo wine memiliki nilai PC1 negatif dan kopi Gayo biasa memiliki nilai PC1 positif secara keseluruhan, sehingga hal tersebut menjelaskan bahwa kedua kopi ini dapat dibedakan oleh PC1. Hasil Principal component (PC) pada diskriminasi PCA MSC moving average 9 segmen yaitu PC1 sebesar 97\% dan PC2 sebesar $3 \%$, sehungga jika nilai PC1 dan PC2 dijumlahkan kedua PC tersebut mendapatkan hasil total varians sebesar $100 \%$. Hasil total varians tersebut dengan jumlah persentase sebesar
$100 \%$ dapat dikatakan sangat baik untuk membangun sebuah model. Jika jumlah peubah dari komponen utama satu PC1 dan dua PC2 lebih besar dari 70\%, maka hasil plot komponen utama memperlihatkan dua dimensi yang baik(Nurcahyo,2015).

\subsection{Model SIMCA MSC+Moving Average $9 \mathrm{~s}$} Hasil PCA MSC Moving Average 9 segmen pada 200 sampel kopi Gayo biasa dan 200 sampel kopi Gayo wine sangat bagus untuk membuat model SIMCA Gayo biasa dan model SIMCA Gayo wine. Sampel setiap jenis kopi sebelumnya sudah dibagi sebagai kalibrasi, validasi, dan prediksi. Masing-masing pembagian sampel pada setiap 200 sampel yaitu 100 untuk kalibrasi, 60 untuk validasi, dan 40 untuk prediksi. dilihat pada Gambar 8 untuk model SIMCA MSC Moving Average 9 segmen Gayo biasa dan Gambar 9 untuk model SIMCA MSC Moving Average 9 segmen Gayo wine. 


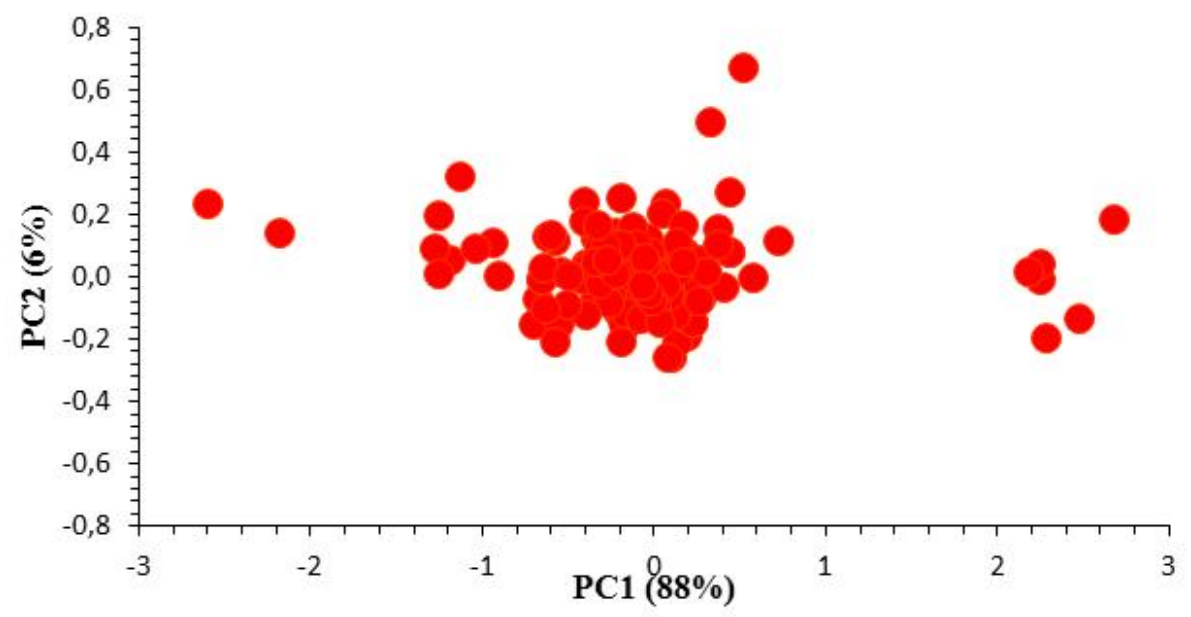

Gambar 8. Model SIMCA Menggunakan Spektra MSC Moving Average 9 Segmen Kopi Gayo Biasa

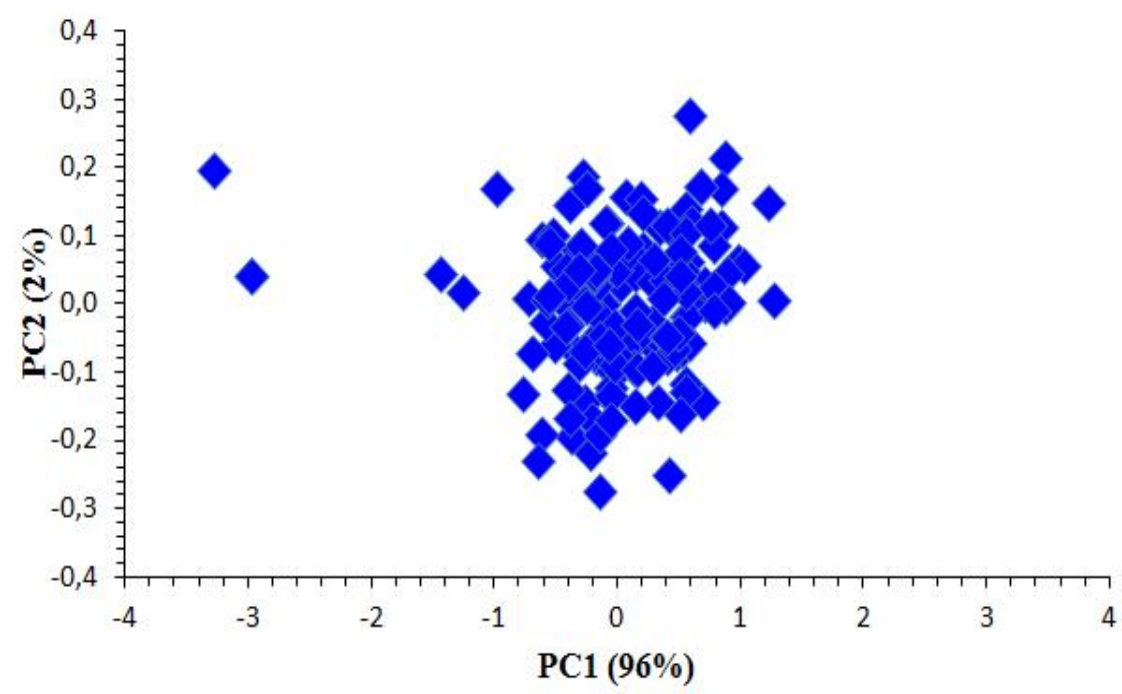

Gambar 9. Model SIMCA Menggunakan Spektra MSC Moving Average 9 Segmen Kopi Gayo Wine

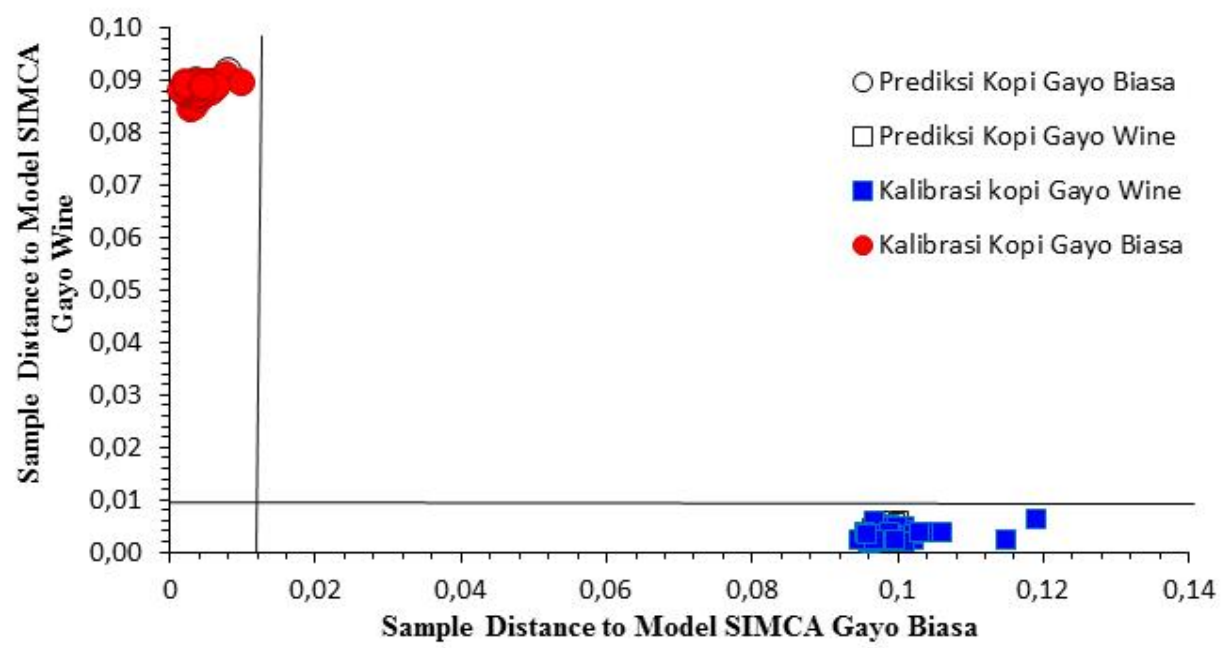

Gambar 10. Commans Plot MSC+MA 9s pada Microsoft Excel 
Tabel 2. Confusion Matrix Berdasarkan MSC Moving Average 9 segmen

\begin{tabular}{lcc}
\hline & Kelas A (Model SIMCA A) & Kelas B (Model SIMCA B) \\
\hline Kelas A (aktual) & 39 & 0 \\
Kelas B (aktual) & 0 & 39 \\
\hline a) Akurasi (AC) & $=\frac{a+d}{a+b+c+d} \times 100 \%=\frac{39+39}{39+0+0+39} \times 100 \%=100 \%$ \\
b) Sensitivitas (S) & $=\frac{d}{b+d} \times 100 \%=\frac{39}{0+39} \times 100 \%=100 \%$ \\
c) Spesifisitas (SP) & $=\frac{a}{a+c} \times 100 \%=\frac{39}{39+0} \times 100 \%=100 \%$ \\
d) Error (FP) & $=\frac{c}{a+c}$ & $\times 100 \%=\frac{0}{39+0} \times 100 \%=0 \%$
\end{tabular}

\subsection{Klasifikasi Kopi Gayo Wine dan Kopi Gayo Biasa Menggunakan Spektra MSC+Moving Average $9 \mathrm{~s}$}

Sampel prediksi yaitu 40 sampel kopi Gayo biasa dan 40 sampel kopi Gayo wine akan diidentifikasi menggunakan model SIMCA yang sudah dibuat yaitu model SIMCA Gayo biasa untuk sampel kopi Gayo biasa dan model SIMCA Gayo wine untuk sampel kopi kopi Gayo wine. Setelah dilakukan klasifikasi terhadap 40 sampel prediksi Gayo biasa dan 40 sampel kopi Gayo wine, selanjutnya dilakukan perhitungan Confusion Matrix kembali untuk mengetahui nilai akurasi, sensitivitas, spesivitas, dan error pada perbaikan data MSC Moving Average 9. Perhitungan Confusion Matrix dapat dilihat pada Tabel 2.

Dari hasil perhitungan Confusion Matrix didapatkan nilai akurasi, sensitivitas, dan spesifitas yang sangat tinggi Pada hasil perhitungan Confusion Matrix berdasarkan hasil klasifikasi menunjukkan bahwa terdapat nilai akurasi(AC) sebesar 100\%,sensitivitas (S) sebesar 100\%,spesifisitas (SP) sebesar $100 \%$,dan nilai error (FP) sebesar $0 \%$.

Hasil klasifikasi model SIMCA Gayo biasa dan SIMCA Gayo wine berdasarkan perbaikan data MSC Moving Average 9 segmen dari 40 sampel prediksi masing-masing jenis kopi. Pada sampel prediksi kopi Arabika Gayo biasa terdapat 39 sampel yang masuk model SIMCA Gayo biasa dan pada sampel prediksi Gayo wine terdapat 39 sampel dari 40 sampel prediksi kopi Gayo wine yang masuk ke dalam model SIMCA kopi Gayo wine. Terdapat 1 sampel prediksi kopi Gayo wine dan 1 sampel prediksi kopi Gayo biasa yang tidak masuk ke dalam model SIMCA manapun yaitu sampel prediksi Gayo biasa GB89A dan sampel prediksi Gayo wine GW94A. Pada hasil klasifikasi ini tidak ada sampel yang masuk ke dalam 2 model sekaligus yaitu model SIMCA kopi Gayo biasa maupun model SIMCA kopi Gayo wine. Hal ini dapat dilihat pada garfik commons plot Gambar 10.

\section{KESIMPULAN DAN SARAN}

\subsection{Kesimpulan}

Berdasarkan hasil penelitian ini maka dapat disimpulkan bahwa:

1. Nilai faktor dari PCA original memberikan informasi PC1 sebesar 97\% dan PC2 sebesar 2\% dimana nilai PC1 lebih besar dibandingkan PC2, sehingga PC1 dan PC2 menunjukkan nilai keragaman data sebesar $99 \%$ untuk keseluruhan data.

2. Hasil bangun Model SIMCA menggunakan perbaikan data MSC dan moving average 9 segmen memberikan informasi pada Model SIMCA kopi Gayo biasa yang dibangun memiliki jumlah nilai PC1 dan PC2 pada Model SIMCA kopi Gayo biasa dan Model SIMCA kopi Gayo wine berturut-turut sebesar $94 \%$ dan 98\%. Model SIMCA yang dibangun sangat baik karena jumlah dari PC1 dan PC2 di atas 70\%.

3. Hasil klasifikasi sampel prediksi menggunakan spektra kombinasi MSC dan moving average 9 segmen sebanyak 40 sampel dalam masing-masing jenis kopi yaitu kopi Gayo biasa dan kopi Gayo wine diperoleh nilai akurasi (AC) sebesar $100 \%$, nilai sensitivitas (S) sebesar $100 \%$, nilai spesifisitas (SP) sebesar $100 \%$, dan nilai error (FP) sebesar $0 \%$. 


\subsection{Saran}

Pada penelitian selanjutnya akan lebih baik jika ditambah varian kopi Gayo lainnya yang digunakan untuk menguji tingkat pengelompokkan dari model yangdibuat oleh teknik kemometrika seperti PCA dan SIMCA. Selain itu diharapkan pada penelitian selanjutnya juga menguji kandungan senyawa apa saja yang terkandung dalam kopi Gayo tersebut.

\section{UCAPAN TERIMAKASIH}

Penelitian ini merupakan bagian dari penelitian yang didanai oleh Kemenristekdikti melaui hibah Penelitian Strategis Nasional Institusi (PSNI) Tahun 2018.

\section{DAFTAR PUSTAKA}

[Ditjenbun]Direktorat Jenderal Perkebunan.2017.http:// ditjenbun.pertanian.go.id/tinymcpuk/ gambar/file/statistik/2017/Kopi -2015-2017.pdf. (Diakses pada tanggal 25 April 2018)

Farhaty,N., Muchtariadi. 2016. Tinjauan Kimia Farmakologi Senyawa Asam Klorogenat pada Biji Kopi. Farmaka.(14)1:218

[ICO]International Coffea Organization. 2018. http://www.ico.org/documents/ cy2017-18/cmr-0318-e.pdf. (Diakses pada tanggal 11April 2016).

Iriani, R. 2016. Studi Penggunaan UV-Vis Spectroscopy dan Kemometrika Untuk Mengidentifikasi Pemalsuan Kopi Arabika dan Robusta Secara Cepat.
Skripsi. Universitas Lampung. Bandar Lampung.

Maramis, R.K., G. Citraningtyas., dan F. Wehantouw. 2013. Analisis Kafein Dalam Kopi Bubuk Di Kota Manado Menggunakan Spektrometer UV-VIS. PHARMACON. 2(4): 122-128.

Panggabean, E. 2011. Buku Pintar Kopi. PT Agro Media Pustaka. Jakarta Selatan. hlm 2-5.

Pratiwi, M.T. 2018. Studi Penggunaan Data Spektra di Daerah Ultraviolet Viseible dan Metode PLS-DA untuk Diskriminasi Beberapa Kopi Specialty Indonesia. Skripsi. Universitas Lampung. Bandar Lampung.

Pietro,B.G. 2017. Novel variable influence on projection (VIP) methods in OPLS, O2PLS, and OnPLS models for single- and multiblock variable selection. Thesis. Department of Chemistry Industrial Doctoral School, Umeå University. Swedan. $120 \mathrm{hlm}$.

Sahat, S.F. 2015. Analisis Pengembangan Kopi Ekstrak Sebagai Upaya Diversifikasi Ekspor Kopi di Indonesia. Thesis. Insitut Pertanian Bogor. Bogor. 80 hlm.

Souto, U. T. C. P., M.F, Barbosa., H.V, Dantas,. A.S, Pontes,. W.S, Lyra,. P.H.G.D, Diniz,. M.C.U, Araujo,. and E.C, Silva. 2015. Identification of Adultration in Ground Roasted Coffees Using UV-Vis spectroscopy and SPA-LDA, LWT- Food Science and Technology 30: 1-5. http://dx.doi.org/10.1016/ j.lwt.2015.04.003 